\title{
Mental accounting in the Housing Market*
}

\author{
Johan Almenberg ${ }^{\dagger}$ and Artashes Karapetyan ${ }^{\ddagger}$
}

August 14, 2010

\begin{abstract}
We report evidence that salience may have economically significant effects on homeowners' borrowing behavior, through a bias in favour of less salient but more costly loans. We outline a simple model in which some consumers are biased. Under plausible assumptions, the bias may affect prices in equilibrium. Market data support the predictions of the model.
\end{abstract}

Keywords: salience, housing market, household finance, co-op, capital structure JEL codes: D12, G14, G21, G32

${ }^{*}$ We thank Anna Dreber, Peter Englund, Christian Ewerhart, Magnus Johannesson, Yannis M. Ioannides, Stephan Meier, Robertas Zubrickas, seminar participants at the Stockholm School of Economics and several anonymous referees for helpful comments and suggestions. We thank HSB Riksförbund for sponsoring our survey and Mäklarsamfundet, Värderingsdata, and Boreda AB for supplying market data. Johan Almenberg thanks the Jan Wallander and Tom Hedelius Foundation, and the Torsten and Ragnar Söderberg Foundations, for financial support.

${ }^{\dagger}$ Swedish Ministry of Finance.

${ }^{\ddagger}$ Norges Bank. 


\section{Introduction}

Households face many choices that require financial judgment. When this judgment falls short of the mark, households may make financially suboptimal decisions. In some cases, failing to optimize entails a negligible cost; in other cases, the cost is large. Depending on the market in question, sub-optimal decisions of individual participants may or may not affect the market equilibrium.

This paper examines certain aspects of a decision faced by many households: making a debt-financed acquisition of a home. We document some strong indications that borrowing decisions are not always rational in the housing market. The setting we examine is the Swedish housing market, in which virtually all apartments are organized as housing co-operatives ("coops"). Co-ops can, and frequently do, take on debt. As a result, a household acquiring an apartment evaluates different combinations of personal loans and co-op loans.

The Swedish housing market is interesting because the cost of financing an apartment through a co-op loan and through a personal loan differ substantially. Interest payments on personal loans are tax deductible, whereas interest payments on co-op loans are not. As a result, individuals financing their apartments through co-op loans face considerably higher borrowing costs net of taxes. Despite this, co-op loans account for a considerable share of apartment financing: in 2008, the total debt held by Swedish co-ops amounted to 220 billion SEK or about 29 billion USD, equivalent to more than half of the total assessed value of these co-ops. ${ }^{1}$ The amount of money left on the table is economically significant: in 2006, the most recent year for which there is information about co-op interest payments, co-ops on average paid interest equivalent to about 20 USD per square meter. ${ }^{2}$ For an average sized apartment (about 90 square meters, see Statistics Sweden, 2010), this would imply interest payments on co-op loans associated with their apartment amounting to about 1800 USD. This amounts to an average potential saving of about 540 USD per year and apartment if these loans were replaced with tax deductible personal loans.

Co-op loans are less salient, in the sense that they are less visible and easier for the consumer to ignore. Several factors contribute to make co-op

\footnotetext{
${ }^{1}$ Source: Statistics Sweden. 1 USD $=$ approx 7.5 SEK.

${ }^{2}$ Source: Statistics Sweden.
} 
loans less salient. Interest payments are not itemized in the monthly fees, and only the aggregate debt of the co-op is stated in annual co-op reports. When an apartment is for sale, the co-op loan which the buyer would be servicing is not specified in the ad.

Empirical work in public economics has shown that salience may be an important determinant of behavioral responses to taxation (Chetty et al, 2009; Chetty and Saez, 2009; Finkelstein, 2009). A parallel literature in consumer finance has reported that the salience of the act of payment affects consumption (see, for example, Soman, 1999; Prelec and Simester, 2001; Soman, 2006). In the light of this research, it seems a priori plausible that loan salience may affect borrowing decisions.

In the first part of this paper, we report the results from a consumer survey that looks at apartment owners' self-reported awareness of personal and co-op loans. The survey data point to a broad tendency to compartmentalize their housing expenditure with regard to the two kinds of loans, in other words, to engage in mental accounting. Most survey participants reported that they were well-informed about their personal mortgage but completely ignorant about the debt held by their co-op, consistent with co-op loans being less salient. Crucially, the vast majority had never considered the possibility of substituting co-op loans for personal loans, suggesting that they do not hold an integrated view of the financial question at hand, i.e. how to best finance an apartment through a combination of co-op loans and personal loans.

In the second part of the paper, we present a model in which biased consumers interact with unbiased consumers in the housing market and where the bias distorts market prices in equilibrium. A bias toward less salient debt is modelled as an additional cost attached to personal loans but not to co-op loans. We think of this as a psychological cost arising from personal loans being more salient. We assume that there is an idiosyncratic component to the utility that an individual gets from an apartment. This is a realistic description of most housing markets and in our model it prevents the separating equilibrium that would arise if different apartments where perfect substitutes. In addition, we assume that individual market participants cannot carry out arbitrage. The Swedish market is characterized by rent control and other restrictions on renting out apartments (see, for example, Lind, 2003). Converting owner-occupied apartments into rental apartments would typically entail a significant financial loss. When each household owns a single apartment at a time, transactions costs from moving make it unlikely that arbitrage will correct prices. 
In the third part of the paper, we test the hypothesis that the cost of co-op debt is accurately reflected in market prices. In October 2006, the Swedish government announced that a change of the tax rules for co-ops would be enacted on 1 january 2007. Until this point, interest on co-op loans had been deductible against a special co-op tax. The abolishment of this tax resulted in the large wedge between the cost of financing an apartment through co-op loans and personal loans. All else being equal, this should make apartments with large co-op loans less attractive relative to those with little or no co-op loans. By contrast, our model predicts that apartment prices can deviate from this rational benchmark also in equilibrium if a share of market participants hold a biased view of co-op loans. A simple analysis of market data around the time of the reform suggests that the market did not adjust to this change in fundamentals. The relative price change for high-debt/low-debt apartments has the expected sign, but the magnitude is small and not statistically significant despite a large sample. We conclude that the data provide a strong indication that the market response to this natural experiment was, at best, muted - in line with the prediction of our model.

\section{Survey results}

As a starting point, we conducted a survey of co-op residents. The participants were asked about their personal mortgage loans and about the loans of their co-ops. Bucks and Pence (2006) report that homeowners in general report their mortgage terms reasonably accurately. We also asked if they were aware of the tax advantage of personal loans relative to co-op loans, and whether they had ever considered the possibility of substituting personal loans for co-op loans. The purpose of the survey was to get a better picture of how common it is for co-op residents to hold a view of co-op loans that departs from strict economic rationality, but not to attempt to identify the determinants of such a biased view.

The survey was conducted in February 2008, at the main train station in Stockholm. Participation in the survey was conditional on owning, and being resident in, a co-op apartment. 100 individuals took part in the survey, which lasted approximately 3 minutes for each participant. Participants were rewarded with a lottery ticket worth approximately USD 4 . The mean age of the participants was 45 years, with a minimum of 17 and a mamixum 
of 77. The sex ratio of participants was exactly 1:1. About two thirds of the sample had college education. About one third was currently, or had previously been, a co-op board member.

Below we present our three main findings from the survey. (1) The vast majority of respondents self-reported being well aware of the size of their personal mortgage loan and the associated interest rate. (2) By contrast, the majority of respondents reported being not even approxiately aware of their co-op loan size and/or interest rate. (3) Respondents were on average highly aware of the tax shield differential between individually held debt and co-op debt, and yet most respondents had never even considered the possibility of substituting individually held debt for co-op debt. In sum, our findings point to a pervasive tendency to compartmentalize the two ways of financing an apartment in a manner that departs from strict economic rationality.

We asked survey participants if they knew the size of their personal mortgage loan and the associated interest rate. As shown in Figure 1, the great majority of the participants in our survey reported knowing the exact size of their mortgage and the exact interest rate they were paying. Of those that did not know the exact numbers, about half knew them approximately. Only $5 \%$ of the partcipants did not even approximately know the loan size, and only $13 \%$ did not even approximately know the interest rate.

Figure 1

\section{Awareness of own mortgage size and interest rate}
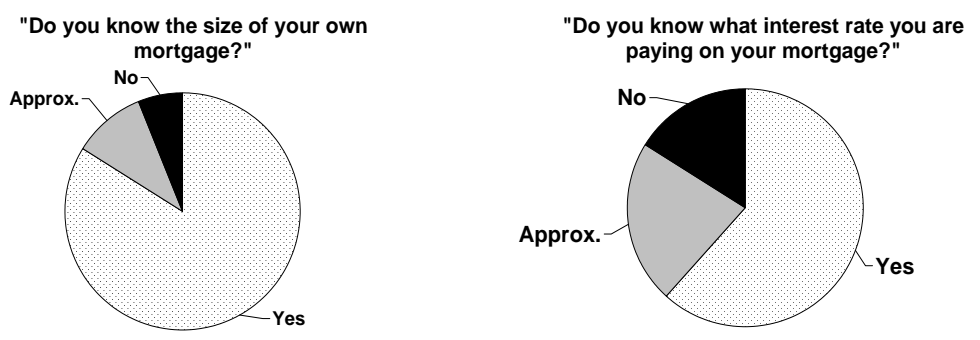

By contrast, only a minority of the participants in the survey reported knowing the sieze of their co-op loan or the associated interest rate. $60 \%$ of respondents did not even approximately know the loan size and $76 \%$ did not even approximately know the interest rate. 
Figure 2

Awareness of co-op debt size and interest rate
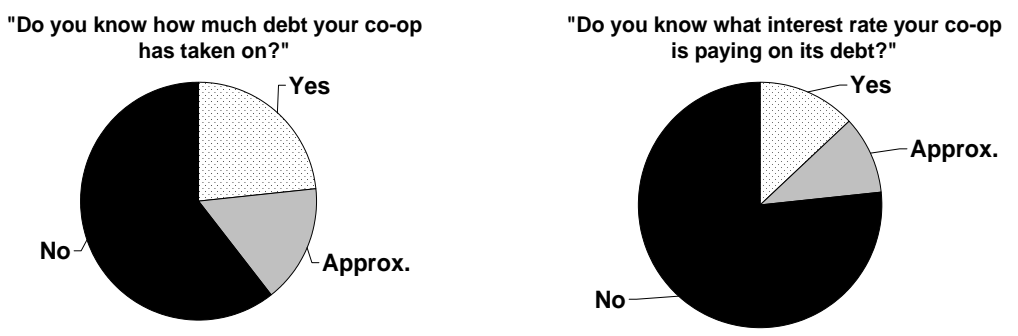

Not all co-ops have loans. Participants stating that their co-ops did not have loans were entered into the data as knowing the exact loan size and the exact interest rate. Participants reporting that they did not think that their co-ops had loans, but were uncertain, were entered into the data as knowing the approximate loan size and the approximate interest rate. This may cause our measure of co-op loan awareness to be biased upwards.

Interest payments on personal loans are tax deductible. An individual's income tax is reduced by an amount equal to 30 percent of interest paid. ${ }^{3}$ By contrast, individuals cannot deduct interest payments on co-op loans. Assuming no difference in gross interest rates, the net cost of capital raised through the co-op is $r$, whereas the net cost of capital raised through an individually held mortgage is $0.7 r$. As shown in Figure 3, survey participants were highly aware of the tax shield differential. ${ }^{4}$

\footnotetext{
${ }^{3}$ Strictly speaking, the deduction is 30 percent of interest paid up to a threshold of SEK 100K (about USD 14K). and 21 percent of interest payments in excess of the threshold. Only a very small fraction (INSERT \%) of Swedish households have interest payments in excess of the threshold, so for simplicity we abstract from this in our analysis.

${ }^{4}$ The option "I don't know" was not offered. Uncertain individuals were asked to indicate which response they thought was more likely to be correct.
} 
Figure 3

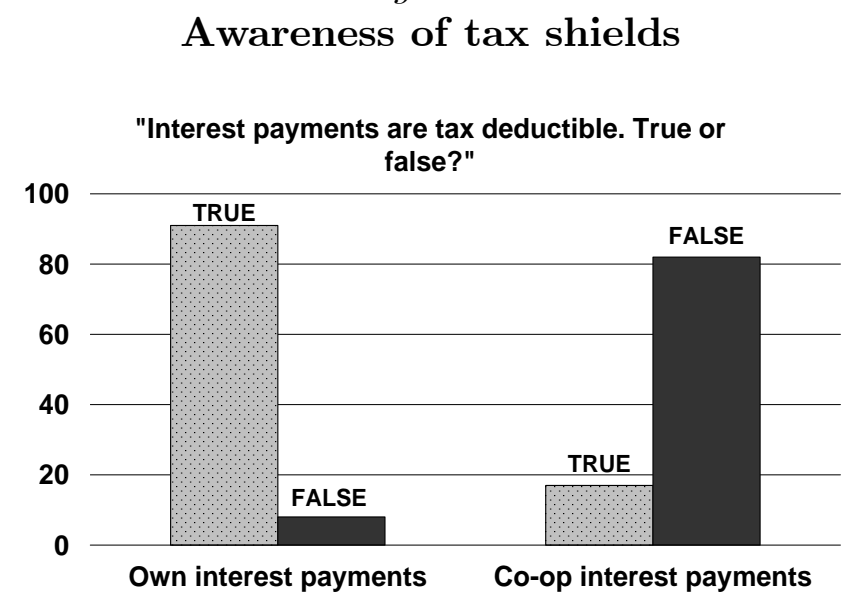

In a financial sense, personal loans and co-op loans are substitutes. An important difference is that personal loans are considerable more salient than co-op loans. The lower salience is underscored by the survey participants' poor awareness of co-op loan size and/or interest rate. The low salience of co-op loans may prevent them from being being replaced with personal loans despite strong economic incentives for doing so. In fact, we found that the vast majority ( 86 percent) of the survey participants had never even considered the possibility of replacing co-op loans with personal loans.

\section{Figure 4 \\ Awareness of debt substitution}

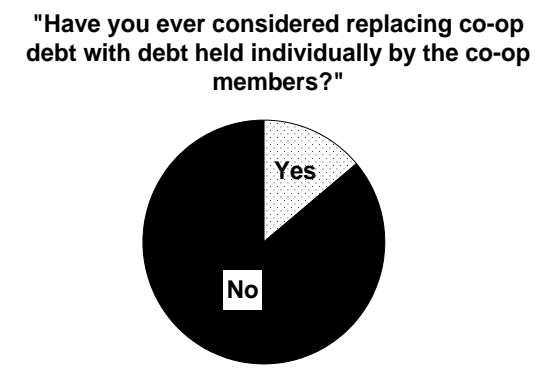

At the end of the survey, we included the following question: "How much is 2 million divided by 5?". This question is a simplified version of the so called "lottery question" used by Banks and Oldfield (2006) and Lusardi and Mitchell (2007) to test numeracy skills. Respondents were given as much 
time as they needed to answer the question. Individuals that provided an incorrect answer but then corrected themselves were entered into the data as providing a correct answer. Despite this, one third of the respondents were not able to correctly answer the question. This is in fact slightly higher than the fraction of correct answers found in the two aforementioned studies that use the lottery question (50.8\% and $55.9 \%$ respectively). The difference may be explained in part by the slightly simpler phrasing in our survey, or by the fact that participation in our survey was conditional on owning an apartment, which may be positively correlated with numeracy skills.

We wish to emphasize the poignancy of this finding: one third of our sample of adult home owners were unable to divide 2 million by 5 without using an aid. In our view, it is highly plausible that many of these individuals will not have a good understanding of the economic costs of not paying attention to less salient but more expensive credit, such as co-op loans.

\section{A simple model of the co-op market}

Our survey results support the view that a sizeable fraction of market participants have a biased perception of a less salient form of debt financing, co-op loans. An important question is whether a bias at the individual level translates into market outcomes - in this case, asset prices - that are inefficient in a narrow economic sense. In the following section, we model the interaction of biased ("naive") and unbiased ("sophisticated") agents in the market place.

One approach for modelling quasi-rational behavior is to treat it as a mistake that occurs when the agent converts raw information into a budget set (Russell and Thaler, 1985). This allows for a distinction between individual differences in (1) preferences, (2) information, and (3) the mapping from the real world to the mental representation of a budget constraint. Having arrived at a not-quite-accurate budget set, the agent optimizes in the same way that a fully rational agent would.

Our model builds on this approach. Naive and sophisticated agents solve the same optimization problem, but the naive agents perceive a psychological cost associated with personal loans in addition to the cost of capital. This captures the idea that salience has an effect on economic decisions that is similar to a higher cost, consistent with the findings in Finkelstein (2009) and Chetty et al (2009). The psychological cost introduces a wedge between the 
two types of debt-financing regardless of differences in the tax treatment. It is immaterial for our results whether this wedge is modelled as an additional cost of personal loans or an additional benefit of the less salient co-op loans.

\subsection{The model}

A continuum of agents on $[0,1]$ decide on purchasing an apartment. For simplicity, we assume that all agents finance their purchases through debt through a convex combination of personal loans and co-op loans. We refer to this combination as the agent's preferred capital structure. Personal loans can be thought of as either personal mortgage loans or personal savings with a required return equal to the rate of borrowing. For ease of exposition, we refer to personal loans as equity and to co-op loans as debt.

Let the gross interest rate $r$ be the same for both equity and debt. The cost of capital is tax deductible for equity but not for debt, and all agents understand this difference when considering the optimal capital structure. Letting $\tau$ denote the tax rate, the net cost of a unit of capital raised as equity is $(1-\tau) r$.

In essence, all agents solve the same maximization problem, but some agents use an incorrect mapping from the information set to the budget set. They get disutility from the higher salience of equity, and fail to perceive the economic costs of the resulting sub-optimal capital structure.

We model this bias as a psychological cost $c_{j}$ that is proportional to the interest paid on equity. Fraction $\alpha$ of all agents are sophisticated (type $j=1$ ) and do not perceive a psychological cost. Fraction $1-\alpha$ are naive (type $j=2$ ) and do perceive a psychological cost. ${ }^{5}$ The net benefit $b_{j}$ associated with equity is the tax shield less the psychological cost, where the cost is modeled as a convex function of the amont of equity $E$ :

$$
b_{j} E \equiv r \tau E-r(1-\tau) c_{j} E^{2}
$$

where $c_{1}=0$ and $c_{2}>0$.

The initial purchase is financed through a combination of equity and debt, i.e., the agents chose capital structures for their apartments. Normalizing the sum of debt and equity to 1 , we can denote the capital structure associated

\footnotetext{
${ }^{5}$ Alternatively, this could be modeled as a psychological benefit from the less salient co-op debt. Since we are only concerned with the relative cost of the two debt sources, such an approach is equivalent to ours.
} 
with a given equity level as $\{E, 1-E\}$, where $E$ represents the fraction of equity.

Because the net cost of equity differs from the net cost of debt, the price of an apartment depends on its capital structure. The price is given by the function $P(E)$. Agents are not financially constrained. ${ }^{6}$

Once the initial capital structure is chosen it cannot be changed. Each type chooses the capital structure that maximizes their benefits throughout their lives, taking into account the possibility that they will sell the apartment in the future to an agent of a different type. Thus the relative supply of apartments with the two different equity structures is determined by the interaction of the two types of agent in the marketplace.

Sophisticated agents choose the capital structure $\left\{E_{h}, 1-E_{h}\right\}$, and naive agents choose $\left\{E_{l}, 1-E_{l}\right\}$. We show that $E_{h}>E_{l}$. The relative supply of apartments with high and low equity structures is determined by $\alpha$.

In order to choose an apartment, agents make $m=2$ searches at the beginning of period 2. We assume that when searching an agent views one apartment of either capital structure type. Our results do not hinge on this assumption - all we need is that apartments are sufficiently idiosyncratic that a full separation, whereby either agent type trades only with itself, does not occur. This realistic feautre of the housing market is captured through the (separately additive) idiosyncratic utility $v_{i}$, uniformly distributed on $[-V, V]$, that an agent receives when matched with an apartment. ${ }^{7}$ For simplicity, we assume that agents do not anticipate this in the first period.

Agents live for two periods. At the beginning of period 1 they make their initial purchase for which they choose a capital structure that maximizes their benefits throughout their lives. After living in the apartment for one period, agents search for new apartments at the beginning of period 2. If they find an apartment that suits them even better they trade. If not, they remain in the same apartment in the second period.

\footnotetext{
${ }^{6}$ We will abstract from the following aspects: (1) Co-op screening. The co-op has veto rights over new members, but in Sweden these rights are very weak. (2) Pros and cons of the co-op versus other forms of ownership. In Sweden, owner-occupied apartments are without exception organized as co-ops. The condominium ownership structure is not permitted. Thus, we take the co-op ownership structure as exogenously given. (3) Default. Rising prices over the last decade have resulted in lower LTV-ratios for co-ops. When the leverage is moderate, default is highly unlikely. For this reason we will abstract from the difference between the two forms of financing in the case of default.

${ }^{7}$ The model is tractable for a general number of searches, but this does not offer further insight.
} 


\subsection{Determining the price}

We solve for the equilibrium by backward induction. First, we see how agents decide on trading their apartments once they have chosen capital structures. Next, we solve for the first period, in which agents choose capital structures anticipating their likelihood of moving to a new apartment and the future resale value of their initial purchase.

\subsubsection{Period 2: Trading}

The equilibrium price equates supply and demand for apartments of both types of capital structure. The supply of $E_{h}$ and $E_{l}$ apartments depends on $\alpha$ and is determined in period 1. Below, we calculate the demand in several steps.

By assumption each agent considers one apartment with high equity and one with low equity. Both types may settle for an apartment with high or low equity, whichever gives them the higher utility given the realization of the random variable $v$. Suppose for simplicity that the individual utility of monetary payoff $M$ is $u_{i}(M)=M$. Then an agent of type $j$ will trade their initial purchase for an apartment of equity level $E_{h}$ if

$$
v_{i}^{a}-P_{h}+\left(E_{h}\right) b_{j}>v_{0}-P_{0}+\left(E_{0}\right) b_{j}
$$

and

$$
v_{i}^{a}-P_{h}+\left(E_{h}\right) b_{j}>v_{i}^{a^{\prime}}-P_{l}+\left(E_{l}\right) b_{j}
$$

where $a^{\prime}$ denotes the low equity apartment, and $a$ the high equity apartment. $P_{h}$ and $P_{l}$ are the prices of high and low equity apartments, respectively. The parameter $b_{j}$ is the net benefit of equity as defined above. It includes both the psychological cost and the value of the tax shield. Condition (2) states that the agent will move to a new apartment if the sum of the utility from living in the new apartment and the net benefits associated with its capital structure, less the cost $P_{h}$ of purchasing the new apartment, is greater than what the agent earns by staying in the initial purchase (subscripts 0).

The probability that a sophisticated agent trades a high equity apartment for another high equity apartment in the second period is

$$
P_{1}^{h} \equiv P\left\{v_{i}^{a}-\left(P_{h}\right)+E_{h} b_{1}>v_{i}^{a^{\prime}}-\left(P_{l}\right)+E_{l} b_{1}\right\} \times P\left\{v_{i}^{a}>v^{0}\right\}
$$


where the last term is calculated from (1) for type $j=1$.

Similarly, the probability that the agent will stay in their current $E_{h}$ apartment is

$$
P_{1}^{0} \equiv P\left\{v^{0}-\left(P_{h}\right)+E_{h} b_{1}>v_{i}^{a^{\prime}}-\left(P_{l}\right)+E_{l} b_{1}\right\} \times P\left\{v_{i}^{a}<v^{0}\right\}
$$

The total demand by agents of type $j=1$ for high equity apartments is $\Pi_{1}^{h}=P_{1}^{h}+P_{1}^{0}$.

The probability that naive agents will move from low equity apartments to high equity apartments can be calculated in the same manner. The equilibrium price equates supply and demand in the market for high equity apartments:

$$
\alpha \Pi_{1}^{h}+(1-\alpha) \Pi_{2}^{h}=\alpha
$$

where $\alpha$ is the proportion of sophisticated agents, as before. Similarly, the equilibrium price equates supply and demand for the low equity apartments:

$$
\alpha \Pi_{1}^{l}+(1-\alpha) \Pi_{2}^{l}=1-\alpha
$$

where $\Pi_{2}^{l}=P_{2}^{l}+P_{2}^{0}$, analogous to the total demand for high equity apartments.

Proposition 1 The equilibrium price of high equity apartments is given by

$$
P_{h}=P_{l}-2 \alpha V+V+\left(E_{h}-E_{l}\right)\left(r t-(1-\alpha) c_{2}(1-r) \tau\left(E_{h}+E_{l}\right)\right)
$$

Note that the price is decreasing in the psychological cost $c_{2}$, which causes the price of high equity apartments to be lower than the price of low equity apartments.

Proof: See Appendix A.

This is consistent with our survey finding that many agents indeed do not consider substituting equity for debt, even though they understand the tax advantages of equity. The prevalence of such behavior in the market decreases the price of high equity apartments compared to what one would observe given the favorable tax treatment of equity relative to debt. ${ }^{8}$

Proposition 2 The price response to a change in the tax advantage of equity relative to debt is smaller, in absolute terms, when some agents are naive.

\footnotetext{
${ }^{8}$ Note that the price differential is not necessarily decreasing with $\alpha$.
} 
Proof: In an economy without naive agents, i.e., when $c=0$ and/or $\alpha=1$,

$$
\frac{\delta\left(P_{h}-P_{l}\right)}{\delta \tau}=\left(E_{h}-E_{l}\right) r
$$

which is larger, in absolute terms, than the response that the model predicts when $c_{j}>0$ for at least one type $j$, and $\alpha<1$ :

$$
\frac{\delta\left(P_{h}-P_{l}\right)}{\delta \tau}=-\left(E_{h}-E_{l}\right)\left(r-(1-\alpha) c(1-r)\left(E_{h}+E_{l}\right)\right)>-\left(E_{h}-E_{l}\right) r
$$

In other words, if there are naive agents in the market, then we expect equilibrium prices to be less responsive to a change in the relative cost of the two sources of financing. We explore this hypothesis in the first empirical analysis section.

\subsubsection{Period 1: choosing capital structure}

When choosing capital structures, agents maximize their tax benefits, less the psychological cost of equity, and the expected gain or loss from trading in the second period. In addition, each type of the agent chooses an optimal capital structure taking into account the optimal choice of the other type.

Proposition 3 Naive agents choose a lower level of equity, relative to sophisticated agents, when determining their capital structures in period 1.

Proof Naive agents weigh the tax benefits of equity against the psychological cost:

$$
\max _{E} r \tau E-r E-(1-E) r-c E^{2}
$$

From the first-order condition we get the optimal level of equity for naive agents:

$$
E_{l}=\frac{r \tau}{2 c}
$$

while sophisticated agents prefer not to hold any debt at all, so $E_{h}=1, D_{h}=$ $0^{9}$

\footnotetext{
${ }^{9}$ One could internalize the optimal choice of equity by imposing a nonlinear cost of raising it. While such an assumption would be innocuous and more realistic, it does not add insight in our model, since our interest lies in the workings of the trade in period 2 for any high and low equity apartments chosen by agents.
} 


\section{An empirical test}

Our survey results suggest that many apartment owners have a biased view of co-op loans: they are unaware of co-op loan size and interest, and even though they understand the differential tax treatment, they have not considered replacing co-op loans with personal loans. Our model predicts that the presence of these biased market participants might generate asset prices that depart from economic fundamentals.

We use sales data provided by the Swedish association of real estate agents to test the hypothesis that co-op loans are not properly accounted for in apartment prices.

The co-op loans are not in the data. Instead, we use the monthly fee as a proxy. The correlation is strong. Boreda $\mathrm{AB}$, a firm specializes in analyzing co-op annual reports, provided us with the correlation between the fee $/ \mathrm{m}^{2}$ and co-op debt $/ \mathrm{m}^{2}$ in their (proprietary) data during the same time period. The correlation coefficient for their sample is about 0.66 when controlling for year of construction, as we do.

On 16 October 2006 the government announced that the supplementary housing tax levied on co-ops would be abolished on 1 January 2007. At the time, all co-ops were required to pay a basic housing tax amounting to 0.5 percent of the assessed value of the property. In addition, co-ops paid a 28 percent tax on an imputed rent amounting 3 percent of the assessed value. Interest rate payments made by the co-op, however, were deductible against this tax. Hence co-ops with large loans did not pay the tax, and would not be affected by the reform. By contrast, co-ops with little or no loans received a considerable cost reduction.

Rational consumers should have anticipated that co-ops with low leverage would either (1) reduce their monthly charges in the future, or (2) maintain the same monthly fee but increase the flow of services. Thus, in an efficient market we would expect a positive price effect for apartments in co-ops with little or no debt. To separate this effect from general price movements, we focus our attention on changes in the relative price of co-ops with large and small loans around the time of the reform. In an efficient market, this relative price should change in favour of co-ops with small loans.

We test this hypothesis using data on more than three thousand apartment sales that took place throughout the country within 30 days of the announcement of the reform. The data distinguishes between the transaction date and the moving date. We use the transaction date to divide the 
sample into pre-reform and post-reform sales. We control for the monthly fee, apartment size, the number of rooms, the floor, the age of the building, whether the building has an elevator, and the municipality.

The summary statistics presented in Table 2 show that the two subsamples are closely similar. The large standard deviation for the price per square meter is due to the fact that price levels cary considerably between regions. In the regressions, we control for municipalities. As a precaution, we compare the mean and variance of fees before and after the reform. Since prices are set by both demand and supply, a change in the relative supply of apartments with large and small co-op loans (high and low fees) during this period this could also have affected the equilibrium price. Statistical tests fail to reject both the null hypothesis of equal means, and the null hypothesis of equal variance, between the two periods (two-sample $t$-test; $p$-value: $0.52 /$ Levene statistic; $p$-value: 0.99$)$.

Table 2

Summary statistics

\begin{tabular}{lccccc}
\hline & \multicolumn{2}{c}{ Pre-reform $(\mathrm{n}=1,601)$} & & \multicolumn{2}{c}{ Post-reform $(\mathrm{n}=1,451)$} \\
\cline { 2 - 3 } \cline { 5 - 6 } Variable & Mean & Standard deviation & & Mean & Standard deviation \\
\hline Price/m2 & $19,782.01$ & $13,409.86$ & & $20,017.16$ & $14,293.28$ \\
Annual fee/m2 & 598.29 & 140.85 & & 599.59 & 142.89 \\
Balcony & 0.42 & 0.49 & & 0.41 & 0.49 \\
Elevator & 0.43 & 0.50 & & 0.39 & 0.49 \\
Construction year & 1958 & 38.76 & & 1955 & 39.45 \\
Rooms & 2.78 & 0.90 & & 2.82 & 0.94 \\
Floor & 2.11 & 1.97 & & 1.97 & 1.79 \\
\hline \hline
\end{tabular}

Next, we fit a hedonic model with the price per square meter as the dependent variable. We include the co-op loan proxy (the co-op fee per square meter) as an explanatory variable, a dummy variable indicating a post-reform sale, and an interaction term between the loan proxy and the post-reform dummy. We can write our econometric model as

$$
y_{i}=\delta_{0}+\beta_{1} \text { loan }_{i}+\beta_{2} \text { post }_{i}+\beta_{3} \text { loan }_{i} \times \text { post }_{i}+\mathbf{X}^{\prime} \boldsymbol{\delta}_{i}+\varepsilon_{i}
$$

where the dependent variable, $y$, is the sales price per square meter, loan is the co-op loan proxy, post is the dummy variable indicating a post-reform sale, and $\mathbf{X}$ is a vector of apartment characteristics. 
We are interested in $\beta_{3}$, the coefficient on the interaction term between the co-op loan proxy and the post-reform indicator. More debt should result in a lower price both before and after the reform, but the negative effect of co-op debt should be larger after the reform, because it increased the relative cost of co-op loans compared to personal loans. The coefficient $\beta_{3}$ captures this difference-in-difference. In Appendix B we estimate a benchmark value for $\beta_{3}$ when prices adhere closely to economic fundamentals. According to our estimates, the coefficient $\beta_{3}$ should be in the range of -7 to -11 if the market accurately reflected the change in fundamentals. The regression estimates for the key variables are reported in Table 2 .

Table 3

\section{Effect of co-op loans on price per sqm}

\begin{tabular}{lc}
\hline OLS regression. Dependent variable: price per sqm. & \\
\hline Co-op fee, SEK per sqm & -18.37 \\
& $(0.000)^{* * *}$ \\
Dummy variable for being a post-reform sale & $1,338.6$ \\
& $(0.213)$ \\
Interaction term for co-op fee and being a post-reform sale & $\mathbf{- 1 . 8 4}$ \\
& $\mathbf{( 0 . 2 9 8 )}$ \\
Additional controls & Yes \\
Constant & $56,795.00$ \\
& $(0.000)^{* * *}$ \\
\hline Observations & 3,052 \\
$R^{2}$ & 0.83 \\
Robust p-values in parentheses. $* * *$ significant at $1 \%$ & \\
\hline \hline
\end{tabular}

The coefficient on the interaction term, $\beta_{3}$, has the appropriate, negative sign. The magnitude of the effect, however, is strikingly small: -1.84 , as compared to an estimated rational benchmark in the range of about -7 to -11. The estimated value for $\beta_{3}$ is not statistically different from zero, despite a large sample size and the good fit of the regression $\left(R^{2}: 0.83\right)$. By contrast, the estimated value for for $\beta_{3}$ is statistically different from even the lower end of the range of benchmark values.

Thus we are unable to reject the null hypothesis that the relative price of co-ops with large and small loans did not change following a reform that 
had a large effect on the relative cost of the two sources of financing. This is consistent with our survey finding that many apartment owners appear to have a low awareness of co-op loans. It is also consistent with our model which predicts that when some fraction of the market is biased in this regard, prices in equilibrium will depart from economic fundamentals. In other words, market data indicate that a bias at the individual in favor of less salient debt may very well be translated into inefficient pricing at the market level.

\section{Discussion}

It is well documented that consumers often fail to minimize borrowing costs. Agarwal et al (2006) report that a substantial fraction of consumers choose ex-post sub-optimal credit contracts. ${ }^{10}$ Many credit card holders fail to minimize costs by switching to a cheaper available source of credit, such as another credit card, checking balances or other liquid and low-yielding assets (Gross and Souleles, 2002; Stango and Zinman, 2009). Consumers take out payday loans at very high interest rates even when they have access to cheaper sources of financing (Agarwal et. al, 2009).

The housing market is no exception, despite the economic significance of mortgages at both the micro and macro levels. For many households, their home represents the bulk of their assets, and their mortgage contract is the most important financial contract they ever enter into (Campbell and Cocco, 2003). Sweden, which is the focus of our study, is no exception: real estate amounts to over $70 \%$ of household assets (Campbell, 2006) and the total amount of mortgages outstanding is equivalent to almost $60 \%$ of GDP. ${ }^{11}$ If households make poor mortgage choices it may have serious consequences for their economic well-being and in countries with deep credit markets it may also affect financial stability. Yet many households pay considerably higher mortgage interest rates than they need to, either by failing to refinance their mortgages (Campbell, 2006; Agarwal et al, 2008) or by taking out a subprime mortgage when they would have qualified for a prime mortgage (Lax et al, 2004). Campbell (2006) reports indications that many households choose their mortgage product on non-economic grounds. Borrowers also overpay

\footnotetext{
${ }^{10}$ Switching is no panacea: Wilson and Waddams Price (2010) show that in the UK electricity market about one in six consumers actually reduce their surplus by switching supplier.

${ }^{11}$ Source: Swedish Bankers' Association.
} 
brokers for mortgage origination (Woodward and Hall, 2010). In doing so, large amounts of money are left on the table, leading Woodward and Hall to conclude that many consumers are confused about mortgage origination and do not realize the financial costs of overpaying.

We add to the existing research by identifying a bias in favour of less salient loans that may affect borrowing costs, and housing prices, in equilibrium. Empirical work in public economics has shown that salience may be an important determinant of behavioral responses to taxation. We show that salience may also have economically significant effects on homeowners' borrowing behavior, through a bias in favor of less salient but more costly loans. Our survey results indicate that while Swedish co-op apartment owners are highly aware of the terms of their personal loans, they are largely oblivious of the terms of their co-op loans. Most importantly, the vaste majority had not considered the possibility of substituting one for the other, despite a large difference in net of tax borrowing costs. These results are incompatible with the view that these co-op residents hold an objective view of co-op capital structures. On the contrary, our survey results point to a tendency to compartmentalize the two sources of loan financing as if they were not part of the same optimization problem.

Our model predicts a muted response to a change in the relative cost of the two forms of debt. Market data offers an opportunity for a simple test of this hypothesis. We examine apartment prices before and after a tax policy change in 2006. The observed response has the correct sign but is small in magnitude and not statistically significant. This is consistent with the prediction of our model. Our finding adds to the existing research on how behavioral biases may affect the housing market (see, for example, Genovese and Mayer, 2001; Brunnermeier and Julliard, 2005; Mayer and Sinai 2007).

Co-op loans are less salient but they are also more costly, and a bias in favor of less salient co-op loans may impose substantial costs on individual households. The money left on the table can be large, as illustrated by the numerical example presented in Table 3. The example is based on a personal loan of 2 million SEK, equal to the average price of a Stockholm apartment in 2007. The co-op loan associated with the apartment is 1 million SEK, implying that the value of the apartment is 3 million and the ratio of co-op debt to value is 1:3. At an interest rate of 5 percent, the apartment owner could reduce their monthy borrowing cost by about 1,250 SEK by substituting a personal loan for the co-op loan. The monthly saving is equivalent to 
about $6 \%$ of the average pre-tax monthly wage. ${ }^{12}$

Table 4

Potential cost reduction: a numerical example

\begin{tabular}{lrrr}
\hline \hline & Personal loan (SEK) & Co-op loan (SEK) & Total borrowing (SEK) \\
\hline Before & & & \\
Loan size & $2,000,000$ & $1,000,000$ & $3,000,000$ \\
Net of tax interest rate & $3.50 \%$ & $5.00 \%$ & 10,000 \\
Monthly cost & 5,833 & 4,167 & \\
After & & & $3,000,000$ \\
Loan size & $3,000,000$ & 0 & 8,750 \\
Net of tax interest rate & $3.50 \%$ & $5.00 \%$ & $-1,250$ \\
Monthly cost & 8,750 & 0 & \\
\hline Change in cost of loans & 2,917 & $-4,167$ & \\
\hline \hline
\end{tabular}

Despite potentially large gains for individual households, co-op debt remains prevalent. Each year, Statistics Sweden collects detailed information about multi-familiy dwellings including those owned by co-ops. The sample is representative of the overall population (see Statistics Sweden, 2008) and shows that co-op debt has in fact been increasing steadily, despite the higher cost following the reform on 1 January 2007. The pattern applies to overall debt as well as the average debt per square meter, as shown in Table 5.

Table 5

The evolution of co-op debt 2005-2008

\begin{tabular}{lcccc}
\hline \hline Year & 2005 & 2006 & 2007 & 2008 \\
\hline Aggregate debt (SEK billion) & 186.2 & 202.1 & 209.3 & 218.6 \\
Average debt $/ \mathrm{m}^{2}$ (SEK) & 3,106 & 3,263 & 3,321 & 3,367 \\
Aggregate interest payments (SEK billion) & 8.0 & 8.2 & 8.8 & 9.9 \\
\hline \hline
\end{tabular}

Source: Statistics Sweden.

The popularity of co-op debt, despite the disadvantageous tax treatment, may in part be due to some households being borrowing constrained. If

${ }^{12}$ Source: Statistics Sweden. SEK $18,000 \approx$ USD 2,200. 
banks are unwilling to lend to households but are willing to lend to the coops inhabited by those same households, then co-op debt may be a way to circumvent borrowing constraints, albeit at a high price. On the other hand, disposible income net of co-op fees and interest payments are key determinants when the banks approve mortgage loans, and collateral requirements are typically very low (see, for example, Finansinspektionen, 2010). Using co-op loans instead of personal loans reduces the individual's disposible income by an amount equal to 30 percent of the interest paid. That borrowing constraints also play a part is an interesting prior that merits further study, but to the best of our knowledge there is no research showing that a significant share of Swedish co-op residents are borrowing constrained. By contrast, we have documented that many apartment owners have a confused view of the apartment financing problem and have poor awareness of co-op loan size and interest rate. We have also outlined a model that predicts that a bias in favor of less salient co-op loans may distort both borrowing behavior and prices in equilibrium. The market data that we examine are consistent with this prediction.

Do co-op residents really need to know the terms of the co-ops' loans in order to make economically rational choices? Possibly not. The co-op fee might in fact be a sufficient proxy. But this does not diminish the fact that most of the respondents in our survey, including present and former co-op board members, had never reflected on the substitutability of co-op loans and personal loans. This insight is clearly essential if one is to envisage anything like the correct optimization problem for which either the co-op loan or a proxy like the co-op fee is an input. Individuals lacking this insight will most likely be engaging in mental accounting, treating co-op loans and personal loans as fundamentally separate parts of their personal finances. Their low awareness of co-op loans are likely to prevent them from perceiving the cost of doing so.

What economic policies might mitigate the bias and its effects on market equilibrium? It is quite possible that regulation could go some way in reducing the scope for costly mistakes in this market. Regulation, however, often comes at the cost of imposing restrictions on all market participants. It is important to consider both costs and benefits of different policy options. To give an example, the problem of sub-optimal capital structures could clearly be dealt with by simply banning co-op leverage. We believe this to be an unwise policy choice. Short-term debt is a convenient way for co-ops to distribute unforeseen expenditures, such as the need to adjust the premises to 
fit new building laws, over slightly longer time periods. Banning such debt might protect naive consumers, but also imposes an inconvenience cost on all consumers in the market.

We suggest two policies that would reduce the scope for mistakes without significant infringements on consumer choice. First, the co-op monthly fee could be itemized so that it is readily apparent what fraction of the fee is used for service and maintenance on the one hand, and interest payments on the other hand. This increases the salience of co-op loans. Second, real estate agents could be encouraged to disclose the co-op loan associated with an apartment in their advertisements. This information can be inferred from a co-op's annual statement. It is unlikely, however, that consumers will read annual statements and make the necessary calculations at the early stages of choosing an apartment. Proving the information in the advertisement itself would serve as a timely reminder to the consumer that the value of assets is the sum of equity and debt, and facilitate quick comparisons between apartments with different capital structures.

Both policies would be inexpensive to implement and would help consumers make more informed decisions. We believe that both policies would be well suited to field experiments, and encourage further research along these lines. 


\section{References}

Agarwal, S., Chomsisengphet, S., Liu, C. and Souleles, N. (2006), "Do Consumers Choose the Right Credit Contracts". Unpublished working paper.

Agarwal, S., Driscoll, J. and Laibson, D. (2008), "Optimal Mortgage Refinancing: A Closed Form Solution". NBER Working Paper no 13822.

Agarwal, S, Amromin, G., Ben-David, I., Chomsisengphet, S. and Evanoff, D. D. (2009) "Do Financial Counseling Mandates Improve Mortgage Choice and Performance? Evidence from a Legislative Experiment". Fisher College of Business Working Paper.

Banks, J. and Oldfield, Z. (2006), "Understanding Pensions: Cognitive Function, Numerical Ability and Retirement Savings". Institute for Fiscal Studies Working Paper no. 0605.

Bucks, B. and Pence, K. (2006), "Do Homeowners Know Their House Values and Mortgage Terms?". Finance and Economics Discussion Series 2006-3. Washington: Board of Governors of the Federal Reserve System, 2006.

Brunnermeier, M. K. and Julliard, C. (2008), "Money Illusion and Housing Frenzies". Review of Financial Studies 21(1), 135-180.

Campbell, J. Y. (2006), "Household Finance". Journal of Finance 61(4), 1553-1604.

Campbell, J. Y. and Cocco, J. F. (2003), "Household Risk Management and Optimal Mortgage Choice". Quarterly Journal of Economics 118(4), 14491494.

Chetty, R., Looney, A. and Kroft, K. (2008), "Salience and Taxation: Theory and Evidence". American Economic Review 99(4), 1145-1177.

Chetty, R. and Saez, E. (2009), "Teaching the Tax Code". NBER Working Paper No 14836.

Finkelstein, A. (2009), "EZ-tax: Tax Salience and Tax Rates". Quarterly Journal of Economics 124(3), 969-1010. 
Genesove, D. and Mayer, C. (2001), "Loss and Aversion and Seller Behavior". Quarterly Journal of Economics 116(4), 1233-1260.

Gross, D. and Souleles, N. (2002), "Do Liquidity Constraints and Interest Rates Matter for Consumer Behavior? Evidence from Credit Card Data". Quarterly Journal of Economics 117(1), 149-185.

Lax, H., Manti, M., Raca, P., and Zorn, P. (2004), "Subprime Lending: An Investigation of Economic Efficiency". Housing Policy Debate 15(3), 533-71.

Lind, H. (2003), "Rent Regulation and New Construction: With a Focus on Sweden 1995-2001". Swedish Economic Policy Review 10(1), 135-167.

Lusardi, A. and Mitchell, O. S. (2007a), "Baby Boomer Retirement Security: The Roles of Planning, Financial Literacy, and Housing Wealth". Journal of Monetary Economics 54, 205-224.

Lusardi, A. and Mitchell, O. S. (2007b), "Financial Literacy and Retirement Preparedness. Evidence and Implications for Financial Education". Business Economics 42(1), 35-44.

Poterba, J. M. (1984), "Tax Subsidies to Owner-Occupied Housing: An Asset-Market Approach". Quarterly Journal of Economics 99(4), 729-752.

Regeringens proposition 2006/07:1. Budgetpropositionen för $200 \%$.

Russell, T. and Thaler, R. H. (1985), "The Relevance of Quasi Rationality in Competitive Markets". American Economic Review 75(5), 1071-1082.

Soman, D. (2003), "The Effects of Payment Transparency on Consumption: Quasi-Experiments from the Field". Marketing Letters 14(3), 173-183.

Stango, V. and Zinman, J. (2009), "What do Consumers Really Pay on the Checking and Credit Card Accounts? Explicit, Implicit and Avoidable Costs". American Economic Review: Papers and Proceedings 99(2), 424.429.

Statistics Sweden (2010), Yearbook of Housing and Building Statistics 2010.

Statistics Sweden (2010), Intäkts- och kostnadsundersökningen för flerbostadshus (IKU) 2008. 
Thaler, R. H. (1980), "Toward a Positive Theory of Consumer Choice". Journal of Economic Behavior and Organization 1, 39-60.

Thaler, R. H. (1985), "Mental Accounting and Consumer Choice". Marketing Science 4(3), 199-214.

Wilson, C. and Waddams Price, C. (2010), "Do Consumers Switch to the Best Supplier?". Fortcoming, Oxford Economic Papers

Woodward, S. and Hall, R. (2010), "Diagnosing Consumer Confusion and Sub-Optimal Shopping Effort: Theory and Mortgage-Market Evidence." Unpublished working paper.

Zellermayer, O. (1996), The Pain of Paying. Ph.D. Dissertation, Carnegie Mellon University. 


\section{Appendix A}

\section{Proof of Proposition 1}

Denote

$$
x_{j}^{h}=P_{l}-P_{h}+\left(E_{h}-E_{l}\right) r t-\left(E_{h}^{2}-E_{l}^{2}\right) c_{j}
$$

The probability that an agent of type $j=1$ will prefer a high equity apartment over a low equity apartment is the sum of two terms:

$$
P_{1}^{h} \equiv P\left\{v_{i}^{a}-\left(P_{h}\right)+E_{h} b_{1}>v_{i}^{a^{\prime}}-\left(P_{l}\right)+E_{l} b_{1}\right\} \times P\left\{v_{i}^{a}>v^{0}\right\}
$$

The probability that the agent will stay in their current $E_{h}$ apartment is

$$
P_{1}^{0} \equiv P\left\{v^{0}-\left(P_{h}\right)+E_{h} b_{1}>v_{i}^{a^{\prime}}-\left(P_{l}\right)+E_{l} b_{1}\right\} \times P\left\{v_{i}^{a}<v^{0}\right\}
$$

Denote $\Pi_{1}^{h}=P_{1}^{h}+P_{1}^{0}$.

Therefore, with the above notations

$$
\begin{aligned}
P_{1}^{h}= & \frac{1}{2} P\left\{x_{1}^{h}+v_{i}^{a}>v_{i}^{a^{\prime}}\right\}=\frac{1}{2} \int_{-V}^{V} \frac{1}{2 V} \frac{V+x_{1}^{h}+v}{2 V} d v \\
& =\frac{1}{2}\left(\frac{1}{2}+\left.\frac{1}{2 V} \frac{1}{4 V}\left(x_{1}^{h}+v\right)^{2}\right|_{-V} ^{V}\right)=\frac{1}{2}\left(\frac{x_{1}^{h}}{2 V}+0.5\right)
\end{aligned}
$$

It is simple to show that the second probability is equal to the first, so $0.5 \Pi_{1}^{h}=P_{1}^{h}=P_{1}^{0}$

Thus, the equilibrium conditions will solve

$$
\alpha \Pi_{1}^{h}+(1-\alpha) \Pi_{2}^{h}=\alpha
$$

in the market for high equity apartments and

$$
\alpha \Pi_{1}^{l}+(1-\alpha) \Pi_{2}^{l}=1-\alpha
$$

in the market for low equity apartments. It follows that

$$
\alpha\left(x_{1} / 2 V+0.5\right)+(1-\alpha)\left(x_{2} / 2 V+0.5\right)=\alpha
$$

Noting that $\Pi_{j}^{h}=1-\Pi_{j}^{l}$, we get that the market for low equity apartments clears as well. 
Plugging in the values for $x$ and multiplying both sides by $V$ we get

$$
P_{l}-P_{h}+\left(E_{h}-E_{l}\right)\left(r t-(1-\alpha) c_{2}(1-r) \tau\left(E_{h}+E_{l}\right)\right)+V=2 \alpha V
$$

Similarly, for low equity apartments we get

$$
P_{h}-P_{l}+\left(E_{l}-E_{h}\right)\left(r t-(1-\alpha) c_{2}(1-r) \tau\left(E_{h}+E_{l}\right)\right)+V=2(1-\alpha) V
$$

Proof of Proposition 3 The probability that an agent of type $j=1$ stays in their current apartment is

$$
P_{1}^{0}=\frac{V+x_{1}^{h}}{4 V}
$$

For an for an agent of type $j=2$ the probability is

$$
P_{2}^{0}=0.5\left(1-\frac{V+x_{2}^{h}}{2 V}\right)
$$

Plugging in $x_{1}^{h}$ for $P_{l}-P_{h}$ we get $x_{1}^{h}=2 V \alpha-V+(1-\alpha) c(1-r) t\left(E_{h}^{2}-E_{l}^{2}\right)$ and $x_{2}^{h}=2 V \alpha-V-\alpha c(1-r) t\left(E_{h}^{2}-E_{l}^{2}\right)$, implying that for $j=1$,

$$
P_{1}^{0}=\frac{V+x_{1}^{h}}{4 V}=\frac{2 V \alpha+(1-\alpha) c(1-r) \tau\left(E_{h}^{2}-E_{l}^{2}\right)}{4 V}
$$

and for $j=2$,

$$
P_{2}^{0}=0.5\left(1-\frac{V+x_{2}^{h}}{2 V}\right)=\frac{2 V(1-\alpha)+\alpha c(1-r) \tau\left(E_{h}^{2}-E_{l}^{2}\right)}{4 V}
$$

Note that

$$
\frac{\partial P_{1}^{0}}{\partial c}=\frac{(1-\alpha)(1-r) \tau\left(E_{h}^{2}-E_{l}^{2}\right)}{4 V} \geq \frac{\partial P_{2}^{0}}{\partial c}=\frac{\alpha(1-r) \tau\left(E_{h}^{2}-E_{l}^{2}\right)}{4 V}
$$

as soon as $\alpha \leq 0.5$ 


\section{Appendix B}

In the following seciton, we estimate a benchmark range for the coefficient $\beta 3$.in equation 13 under the assumption that prices reflect economic fundamentals.

Owning an apartment in a co-op is in an economic sense not that different from owning a share of a firm. The apartment owner receives a dividend in the form of an imputed rent, and gets the full upside if the value of the apartment increases. The acquisition of an apartment can be financed either through equity (personal loans or savings with a comparable expected rate of return) or by letting the firm/co-op take on debt. For a rational, risk-neutral agent, the utility flow from an apartment does not depend the specific mix of co-op loans and personal loans. Hence the flow cost that a rational individual is willing to pay for the apartment should be the same regardless of the coop's capital structure. Letting $V, D$, and $E$ denote the value of assets, debt and equity, and $a, b$, and $c$ their respective cost, we can write this condition as

$$
\bar{a} \bar{V}=\bar{b} D+\bar{c} E
$$

with the upper bars indicating variables that are unaffected by the reform.

Solving for $E$ and taking the first derivative w.r.t. $D$ gives the marginal rate of substitution between debt and equity such that the agent is indifferent between different capital structures:

$$
M R S_{D, E}=\frac{\partial E}{\partial D}=-\frac{\bar{b}}{\bar{c}}
$$

Before the reform, $b_{0} \approx c_{0}=(1-\tau) r \Rightarrow M R S_{0} \approx 1$. After the reform, $b_{1}>c_{1} \Rightarrow M R S_{1}>1$. More precisely, $b_{1}=r$ whereas $c_{1}=(1-\tau) r$ as before, implying

$$
M R S_{1}=\frac{r}{(1-\tau) r}=\frac{1}{(1-\tau)}
$$

In other words, the post-reform marginal rate of subsitution for a rational individual is such that a marginal increase of one unit of debt reduces equity by $1 /(1-\tau)$ units.

The fee, however, is a proxy for the interest payment on the debt, $r D$, not the principal $D$. We must adjust for this when estimating the coefficient $\beta_{3}$. In the simplest of worlds, a marginal increase of one unit of interest paid implies an additional $1 / r$ units of debt. It follows that the marginal rate of 
substition between interest payments on co-op debt and the level of equity is given by

$$
M R S_{r D, E}=\frac{1}{(1-\tau)} \times \frac{1}{r}=\frac{1}{(1-\tau) r}
$$

We know that $\tau=0.3$. Reasonable estimates of $r$ for the second half of 2006 would be in the range of 0.05 , approximately corresponding to STIBOR $+2 \%$. As shown in Table 1 , benchmark values for $\beta_{3}$ that are consistent with economic fundamentals are in the range of -7 to -11 .

Table 1

\section{Estimating a rational benchmark}

\begin{tabular}{c|c|c|c|c}
\hline$r$ & $1 /(1-\tau)$ & $\begin{array}{c}\text { Pre-reform } \\
\text { MRS }_{0}=1 / r\end{array}$ & $\begin{array}{c}\text { Post-reform } \\
\text { MRS }_{1}=(1 / r)^{*} 1 /(1-\tau)\end{array}$ & $\begin{array}{c}\text { Benchmark value for } \beta_{3} \\
=\text { MRS }_{1}-\text { MRS }_{0}\end{array}$ \\
\hline 0.04 & 1.43 & -25.0 & -35.7 & -10.7 \\
0.05 & 1.43 & -20.0 & -28.6 & -8.6 \\
0.06 & 1.43 & -16.7 & -23.8 & -7.1 \\
\hline \hline
\end{tabular}

